\title{
The Relationship between Leadership and Employees' Work Motivation in the Regional Secretariat Office of Minahasa Regency
}

\section{Jerry Rommy Herter Wuisang ${ }^{1}(\mathbb{D})$, Stanny Sicilia Rawung 2,* (D), and Jenny Nancy Kaligis 3}

${ }^{1}$ Department of Economic Education, Postgraduate Program, Faculty of Economics, Universitas Negeri Manado, 95618, Minahasa, North Sulawesi Province, Indonesia

2 Department of Economics, Undergraduate Program, Faculty of Economics,

Universitas Negeri Manado, 95618, Minahasa, North Sulawesi Province, Indonesia ${ }^{3}$ Department of Marketing Management, Vocational Education Program, Faculty of Economics, Universitas Negeri Manado, 95618, Minahasa, North Sulawesi Province, Indonesia * Corresponding Author: stannyrawung@unima.ac.id

\section{ARTICLE INFO}

\section{Publication Info:}

Research Article

How to cite:

Wuisang, J. R. H., Rawung, S. S., $\mathcal{E}$ Kaligis, J. N. (2020). The

Relationship between Leadership and Employees' Work Motivation in the Regional Secretariat Office of Minahasa Regency. Society, 8(2), 754-760.

\section{DOI: $10.33019 /$ society.v8i2.270}

Copyright () 2020. Owned by Author(s), published by Society

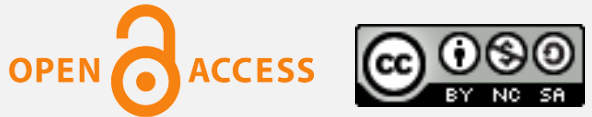

This is an open-access article.

License: Attribution-

NonCommercial-ShareAlike (CC BY-NC-SA)

Received: November 29, 2020; Accepted: December 28, 2020; Published: December 31, 2020;

\section{ABSTRACT}

The major problem facing by the Regional Secretariat of Minahasa Regency is the lack of leaders' attention to employees' motivation and passion at work. This study aims to measure the relationship between leadership and employees' work motivation in the Regional Secretariat Office of Minahasa Regency, North Sulawesi Province, Indonesia. It occupies a central role in advancing employees' work motivation and passion. This study uses a quantitative method to measure leadership's effect on employees' motivation and work passion. Questionnaires were used as the main instrument to obtain the data. These questionnaires were distributed to all respondents in this study. This study's population was predominantly made up of twenty-four employees in the Regional Secretariat Office of Minahasa Regency. Due to the limited population (24 employees), this study used all of the population as the samples. The results of this study showed a significant relationship between leadership and employees' motivation. Since leadership is directing and influencing employees' activity process, leaders should diligently extend it to their organizations utmost.

Keywords: Achievement; Employee; Human Resources; Leadership; Organization; Work Motivation

Copyright (C 2020. Owned by Author(s), published by Society. This is an open-access article under the CC-BY-NC-SA license. 


\section{Introduction}

Essentially, organizations, either governmental organizations or private organizations, tend to strive for their clearly defined goals, the attainment of which is determined by several factors, including their quality and competitive human resources. The success of organizations is not only determined by large asset resources but also human resources. Quality, creativity, perseverance, and discipline are invaluable assets to the success of organizations. Due to their significance, organizations demand human resources with superior quality and outstanding leadership.

Leadership deals with the process of directing and influencing members' occupational activity. This necessitates leaders' uncanny ability to put in their all-out efforts, one of which is providing their employees with positive motivation embodied in a management function. Motivation is a driving force for someone to act due to work challenges and environments, such as friends, leaders, and characters. Work passion is another most decisive factor behind the progress of organizations. Therefore, to maintain employees' loyalty, the leaders are dutybound to devote undivided attention to employees' work passion along with rewards handsomely brought to those with satisfying outcomes (Werther \& Davis, 2006).

Governmental organizations are supposed to provide their employees with the much-need boost to realize highly-motivated employees to achieve more satisfying outcomes. Since employees are partners actively supporting the goal achievement, providing them with strong motivation could arouse their work passion and motivation to do their job well and get a reward or appreciation (Stoner et al., 1996).

The activity of governmental organizations is a joint effort between leaders and employees. Leaders must over-the-top greater attention to employees' welfare to improve their employee's ability and advance the public service.

One of the human-resource-related issues in the Regional Secretariat Office of Minahasa Regency is tardiness, which affects its public services quality. It makes the public must wait patiently. Also, this implies employees' low work motivation and passion. When left untreated correctly, it could decrease the quality of its human resources and its public services. Apart from that, work environments and employees' behavior significantly affect the employee's quality of human resources and discipline.

Furthermore, leaders' suboptimal control creates impacts on employees' job achievement. Good leaders are those superbly encouraging the employees, as leaders' manners and characters influence the employees. Thus, this study's main objective is to examine the relationship between leadership and employee's work motivation in the Regional Secretariat Office of Minahasa Regency.

\section{Literature Review}

\subsection{Leadership}

Several forms of cooperation in daily life, intended to achieve several well-defined goals. The whole process of cooperation forms a pattern of relationships in the organization. By definition, an organization is a process or a sequence conducted by two or more people to achieve specific goals.

Leadership is a key element of an organization's success (Kaligis et al., 2020). Prijosaksono \& Sembel (2002) defined leadership as a decision and a result of character changing process. It refers to someone's positions, titles, and a long-term changing process in his or her characters. According to Clinton (2012), leadership is a dynamically planned process through which 
leaders develop specific patterns and styles of behaviors and use facilities or infrastructures to lead their members into doing worthwhile jobs to their mutual advantages.

The word "leadership" is defined as a close relationship between individuals and groups of people due to a common interest. Great and guided behaviors characterize this relationship. Rivai (2004) stated that leadership includes the process of influencing members in determining organization purposes, motivating their behavior to achieve the goals, and influencing them to improve collective behavior and culture. Siagian (2003) divided leadership types as follows:

1) Autocratic Leadership

This type of leadership refers to complete control power and dependency on the leader. Autocratic leaders tend to justify all the ways to achieve an organization's purposes without their members' input in making organizational decisions.

2) Paternalistic Leadership

This type of leadership tends to overprotect members by providing them with what they need, without responsibility or freedom of choice.

3) Charismatic Leadership

Charismatic leaders are admired by their followers, even though they cannot concretely explain the reasons.

4) Laissez-faire Leadership

This type of leadership deals with permissive attitudes. Members are allowed to act in their ways to achieve common interests and the organization's purpose.

5) Democratic Leadership

This type of leadership encourages its members to develop and improve creativity and prioritizing cooperation in achieving goals.

To sum up, leadership is the ability to encourage, influence, and motivate an individual or a group of people to achieve a specific purpose. To understand the concept of leadership, Bass (2009) proposed transformational leadership theory. This theory, propounded initially by Burns, focuses on a leader's behavior able to encounter the changing progress in all realms. According to Burns, as cited in Yulk (1998), defined leadership as a process of fostering interrelation, where leaders and members influence one another to modify their behavior following the members' perceptions. He described transformational leadership as a process in which leaders and members influence each other at a micro level or even mobilize power to change the social system and upgrade the institution at a macro level. In conjunction with Maslow's Hierarchical theory, leaders motivate their members towards a higher level of necessity. It means the members are guided from their daily condition into a better condition.

Burns (2010) added that organizations' members could follow transformational leadership in various positions and influence other members, partners, or even the leaders. It is in pursuit to raise members' awareness about moral values, such as freedom, justice, equality, peace, and humanism, rather than to provoke members' negative emotions, such as fear, greed, hatred, and jealousy.

Bass (2009) developed Burns' theory by designing this theory in more detail, especially regarding organizations' transformational process. He observed the influence of transformational leadership of leaders' on their members. The leaders change members' mindsets by building awareness about the moral value and the importance of serenity and encouraging them to change their concerns to organizations or common concerns. It makes the members have more trust and respect for their leaders. 
Bass (2009) divided four elements of transformational leadership as follows:

1) The attribute of charisma

Leaders convey an impression that they possess a remarkable capacity and skills to do their job in such a way that they deserve to be appreciated. Leaders have more trust in their ability to get their feelings out when they deal with distressing situations.

2) Intellectual stimulation

Leaders help the members to encounter and solve problems by a new perception. The members could redefine the way they work and take a new perception from their leaders.

3) Individual consideration

It is a behavior comprising support, courage, and experience for the members. It makes the members feel cared for by the leader. The leader treats them as individuals with particular skills, needs, and expectations, giving them advice, listen to their complaints and suggestions, and providing them with training to ensure their confidence to do their jobs.

4) Inspirational leadership

Leaders can inspire their members by determining job standards and believing that they can collaboratively achieve the goals.

Those four elements build a commitment to achieve common goals. Yulk (1998) contended that transformational leaders give the members the courage and change the organization by creating new rules. They extremely give responsibility and authority by removing bureaucratic pressure or rigidity, providing the members training facilities, allowing the participants to make an important decision, building teamwork, supporting constructive problems solving, and conflict resolution.

\subsection{Work Motivation}

Etymologically, motivation comes from the English "motive". This word is derived from the Latin "motion", which means move. Malay borrows the word "motive" and changes it into "motivasi," which means purpose or activator. This "purpose" becomes the main motivation to do hard work to achieve the expected purpose (Hasibuan, 2011).

According to Robbins \& Coutler, as cited in Winardi (2008), motivation is awareness to carry out a high effort to achieve organizational purposes to fulfill a specific individual need. Hasibuan (2011) stated that motivation is a driving force to create people's work excitement to work together effectively and integrally with their efforts and personal purpose.

In conclusion, employees' motives or expectations are the driving force to behave towards organizational purposes. The motivation related to organizational purpose is called internal work motivation, while related to the leader's purpose is called external work motivation (Hasibuan, 2011).

Employees must have a good mental attitude to ensure that they are mentally and physically healthy to understand situations and conditions and strive to achieve the organizational purposes (Mangkunegara, 2015). Theories of motivation which related to that description are exchange theory, expectation theory, and confirmation theory. Theories of motivation in the theory of necessity motivation are similar to satisfaction theory, Maslow's Necessity Theory, Herzberg's Two-Factor Theory, and McClelland's Necessity Theory (Handoko, 2010).

Maslow's Necessity Theory points out the necessity arranged by hierarchy. It comprises psychological necessity, work security and safety necessity, social necessity, esteem necessity, and increasing work capacity necessity. Meanwhile, Herzberg's Two-Factor Theory describes

Copyright (C 2020. Owned by Author(s), published by Society. This is an open-access article under the CC-BY-NC-SA license. https://doi.org/10.33019/society.v8i2.270

757 
two work motivation factors: work environment's hygiene factor and work motivation factor. It highlights that most of the hygiene factors are fulfilled by the organization and the actual work. In contrast, the necessity of esteem is only given to employees who do great jobs. Furthermore, McClelland's Necessity Theory proposes three kinds of motives: to achieve, to affiliate, and to get authority (Handoko, 2010).

Leadership is beneficial to improve employees' work motivation since work motivation influences service and ensures customers' satisfaction. To mobilize the employees, individuals, or groups of employees, the leaders should have the capacity to read the situation and adjust their leadership style to fit the situation they encountered, even though this adjustment could be temporary. Applying proper type of leadership could increase employees' work motivation and influence the organizational purpose achievement. This study formulates its research problem to investigate the relationship between leadership and employees' work motivation in the Regional Secretariat Office of Minahasa Regency.

\section{Research Methodology}

This study uses a quantitative method, and questionnaires were used as the main instrument to obtain the data. These questionnaires were distributed to all respondents in this study. This study used a correlation method to determine the correlation or influence between the $X$ variable and the $Y$ variable. Leadership will be marked as $x$ variable (independent variable). It deals with encouraging, motivating, mobilizing, and influencing individuals or groups of people to achieve a certain purpose. The indicator is the leaders with transformational leadership act as a protector.

Employees' work motivation is marked by the $\mathrm{Y}$ variable (dependent variable). Work motivation is the factors that motivate and mobilize the employees to do their job in an organization under certain internal factors, such as mental, physical, condition, and situation. Figure 1 below describes the framework of the variables.

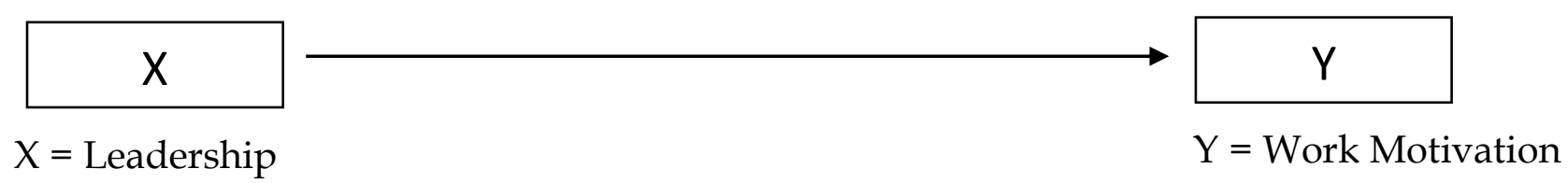

Figure 1. Variables Framework

This study's population was predominantly made up of twenty-four employees in the Regional Secretariat Office of Minahasa Regency, North Sulawesi Province, Indonesia. Due to the limited population (24 employees), this study used all of the population as the samples.

\section{Results and Discussion}

This study used Spearman's Rank Correlation Coefficient for the data analysis with the following equation.

$$
\begin{aligned}
& r_{s}=1-\frac{6 \Sigma d i^{2}}{n\left(n^{2}-1\right)} \\
& r_{s}=1-\frac{1261_{s} 5}{5814} \\
& r_{s}=0.78
\end{aligned}
$$


To test Spearman's Rank Correlation Coefficient, it will need to refer to rho table values to determine this study's significance and to accept or reject the hypotheses. The $r_{\mathrm{s}}$ value is 0.78 with an actual level of $\alpha=0,05$ and $n=24$, and the rho table shows the value of $\rho$ (0.05) of 0.59. Since $r_{s}=0.78>\rho s(0.05)=0.59$, the hypothesis is significant and acceptable. This concludes that there is a significant effect of leadership on employees' work motivation.

The result can be used to measure the difference of rank in pairing observations by using a correlational method. Questionnaires were used as the main instrument to obtain the data. The result comes up with a significant effect of leadership on employees' work motivation. Technically, leadership in organizations and companies is crucial since leaders with good leadership can motivate their employees to work hard to achieve their purpose.

\section{Conclusion}

This study concludes that there is a significant relationship between leadership and employees' work motivation. It is proven by the data analysis showing that $\mathrm{x}$ variable and $\mathrm{y}$ variable gain the value of $r_{\mathrm{s}}=0.78$. Judging from the rho table with an actual level of $a=0.05$ and $n=14$, it fits with the rho table obtaining $s \rho_{s}(0.05)=0.59$. The $r_{s}=0.78>\rho_{s}(0.05)=0.59$ means that the leadership has a significant effect on employees' work motivation.

This conclusion reflects leaders' suggestion to take on a positive leadership attitude and be open-minded to criticisms and suggestions. A good leader will motivate all employees in such a great way that the employees arouse their passion when doing their jobs. Building a strong relationship with the employees is necessary to make them feel seen and heard.

\section{Acknowledgment}

The authors are grateful to express gratitude to those who have had the pleasure to cooperate during this study.

\section{Declaration of Conflicting Interests}

The authors have declared no potential conflicts of interest concerning the study, authorship, and/or publication of this article.

\section{References}

Bass, B. M. (2009). The Bass Handbook of Leadership: Theory, Research, and Managerial Applications. New York, United States: Simon \& Schuster, Inc.

Burns, J. M. (2010). Leadership. New York, United States: HarperCollins Publishers, Inc.

Clinton, J. R. (2012). The making of a leader: Recognizing the lessons and stages of leadership development. Christchurch, New Zealand: NavPress, Inc.

Handoko, T. H. (2010). Manajemen Personalia \& Sumberdaya Manusia (2nd ed.). Yogyakarta, Indonesia: Badan Penerbit Fakultas Ekonomi Universitas Gadjah Mada.

Hasibuan, M. S. P. (2011). Manajemen Sumber Daya Manusia. Jakarta, Indonesia: PT Bumi Aksara. Kaligis, N. Y., Saputan, G. J., \& Pandowo, A. (2020). Analysis of Women Leadership Behavior in the Personnel and Human Resources Development Agency (BKPSDM) of Southeast Minahasa Regency. International Journal of Applied Business and International Management, 37-43. https://doi.org/10.32535/ijabim.v0i0.874

Mangkunegara, A. P. (2015). Perencanaan dan Pengembangan Sumber Daya Manusia. Bandung, Indonesia: PT Refika Aditama.

Prijosaksono, A., \& Sembel, R. (2002). Control Your Life: Aplikasi Manajemen Diri dalam Kehidupan Sehari-hari. Jakarta, Indonesia: PT Elex Media Komputindo. 
Rivai, V. (2004). Kepemimpinan dan Perilaku Organisasi (2nd ed.). Jakarta, Indonesia: PT Raja Grafindo Persada.

Siagian, S. P. (2003). Teori dan Praktek Kepemimpinan. Jakarta, Indonesia: PT Rineka Cipta.

Stoner J. A. F., Freeman, R. E., \& Gilbert, D. R. (1996). Manajemen (2nd ed.). Jakarta, Indonesia: PT Prenhallindo.

Werther, W. B., \& Davis, K. (2006). Human resources and personnel management (5th ed.). New York, United States: McGraw Hill, Inc.

Winardi, J. (2008). Motivasi dan Pemotivasian dalam Manajemen. Jakarta, Indonesia: PT Raja Grafindo Persada.

Yulk, G. (1998). Leadership in organizations. New Jersey, United States: Prentice Hall, Inc.

\section{About the Authors}

1. Jerry Rommy Herter Wuisang obtained his Doctoral degree in Economic Education from Universitas Negeri Malang, Indonesia, in 2014. The Author is an Assistant Professor at the Department of Economic Education, Postgraduate Program, Faculty of Economics, Universitas Negeri Manado, Indonesia.

E-Mail: jerrywuisang@unima.ac.id

2. Stanny Sicilia Rawung obtained her Doctoral degree in Economics from Universitas Hasanuddin, Indonesia, in 2014. The Author is an Assistant Professor at the Department of Economics, Undergraduate Program, Faculty of Economics, Universitas Negeri Manado, Indonesia.

E-Mail: stannyrawung@unima.ac.id

3. Jenny Nancy Kaligis obtained her Doctoral degree in Management Science from Universitas Negeri Jakarta, Indonesia, in 2013. The Author is an Assistant Professor at the Department of Marketing Management, Vocational Education Program, Faculty of Economics, Universitas Negeri Manado, Indonesia.

E-Mail: jennykaligis@unima.ac.id 